\title{
Recent alcohol consumption and risk of incident ovarian carcinoma: a pooled analysis of 5,342 cases and 10,358 controls from the Ovarian Cancer Association Consortium
}

Linda E Kelemen ${ }^{1 *}$, Elisa V Bandera ${ }^{2}$, Kathryn L Terry ${ }^{3,4}$, Mary Anne Rossing ${ }^{5}$, Louise A Brinton ${ }^{6}$, Jennifer A Doherty ${ }^{5}$, Roberta B Ness ${ }^{7}$, Susanne Krüger Kjær ${ }^{8,9}$, Jenny Chang-Claude ${ }^{10}$, Martin Köbel ${ }^{11}$, Galina Lurie ${ }^{12}$,

Pamela J Thompson ${ }^{12}$, Michael E Carney ${ }^{12}$, Kirsten Moysich ${ }^{13}$, Robert Edwards ${ }^{14}$, Clare Bunker ${ }^{15}$, Allan Jensen ${ }^{8}$, Estrid Høgdall ${ }^{8}$, Daniel W Cramer ${ }^{3,4}$, Allison F Vitonis ${ }^{3}$, Sara H Olson ${ }^{16}$, Melony King ${ }^{2}$, Urmila Chandran ${ }^{2}$, Jolanta Lissowska ${ }^{17}$, Montserrat Garcia-Closas ${ }^{18}$, Hannah Yang ${ }^{6}$, Penelope M Webb ${ }^{19}$, Joellen M Schildkraut ${ }^{20}$, Marc T Goodman ${ }^{12,21}$, Harvey A Risch ${ }^{22}$, on behalf of the Australian Ovarian Cancer Study Group and Australian Cancer Study (Ovarian Cancer) and on behalf of the Ovarian Cancer Association Consortium

\begin{abstract}
Background: Studies evaluating the association between alcohol intake and ovarian carcinoma $(\mathrm{OC})$ are inconsistent. Because OC and ovarian borderline tumor histologic types differ genetically, molecularly and clinically, large numbers are needed to estimate risk associations.

Methods: We pooled data from 12 case-control studies in the Ovarian Cancer Association Consortium comprising 5,342 OC cases, 1,455 borderline tumors and 10,358 controls with quantitative information on recent alcohol intake to estimate odds ratios (OR) and 95\% confidence intervals $(\mathrm{Cl})$ according to frequencies of average daily intakes of beer, wine, liquor and total alcohol.
\end{abstract}

Results: Total alcohol intake was not associated with all OC: consumption of $>3$ drinks per day compared to none, $\mathrm{OR}=0.92,95 \% \mathrm{Cl}=0.76-1.10, \mathrm{P}$ trend $=0.27$. Among beverage types, a statistically non-significant decreased risk was observed among women who consumed $>8 \mathrm{oz} / \mathrm{d}$ of wine compared to none $(\mathrm{OR}=0.83,95 \% \mathrm{Cl}=0.68-1.01, \mathrm{P}$ trend $=0.08)$. This association was more apparent among women with clear cell $\mathrm{OC}(\mathrm{OR}, 0.43 ; 95 \% \mathrm{Cl}, 0.22-0.83$; $P$ trend $=0.02$ ), although based on only 10 cases and not statistically different from the other histologic types ( $P$ value for statistical heterogeneity between histologic types $=0.09$ ). Statistical heterogeneity of the alcohol- and wine-OC associations was seen among three European studies, but not among eight North American studies. No statistically significant associations were observed in separate analyses evaluating risk with borderline tumors of serous or mucinous histology. Smoking status did not significantly modify any of the associations.

Conclusions: We found no evidence that recent moderate alcohol drinking is associated with increased risk for overall OC, or that variation in risk is associated strongly with specific histologic types. Understanding modifiable causes of these elusive and deadly cancers remains a priority for the research community.

\footnotetext{
* Correspondence: LKelemen@post.harvard.edu

'Department of Population Health Research, Alberta Health Services-Cancer

Care and Departments of Medical Genetics and Oncology, University of

Calgary, Calgary, AB, Canada

Full list of author information is available at the end of the article
} 


\section{Background}

Carcinomas classified as ovarian are the fourth most common female cancer, accounting for 225,000 (3.7\%) of all new cases and 140,000 (4.2\%) of all cancer deaths globally [1]. Known mutations in high penetrance genes are the best-defined risk factors, explaining $~ 10-15 \%$ of all epithelial ovarian carcinomas [2-6], while common variants in low penetrance genes may account for a smaller fraction $(\sim 3 \%)$ of the polygenic component [7-9]. Non-genetic factors associated with the development of ovarian carcinoma include reduced risk with oral contraceptive use $[10,11]$, number of full-term pregnancies $[12,13]$, long-term breastfeeding [14] and tubal ligation or salpingectomy in BRCA1/2 mutation carriers [12]. The independent contribution of modifiable environmental [15,16] and lifestyle or behavioral [17-21] factors including diet is inconclusive, and only a few studies have confirmed non-genetic risk factor associations according to histologic type [14,22-25].

Several studies examined the association between total alcohol consumption and ovarian carcinoma and reported inverse [17,26,27], null [28-31], or positive [32,33] trends with the highest category of alcohol intake. Increased risk was also found among the mucinous histologic type $[34,35]$. An earlier pooled analysis of prospective studies found no association between $\geq 30 \mathrm{~g} / \mathrm{d}$ total alcohol intake compared to $0 \mathrm{~g} / \mathrm{d}$ among 2,001 cases of ovarian carcinoma (RR, 1.12; 95\% CI, 0.86-1.44), or for alcohol modeled continuously among 121 cases with mucinous histology (RR, 1.06; 95\% CI, 0.84-1.34) [36]. A previous metaanalysis reported no overall association between alcohol consumption and ovarian carcinoma, but did find a 6\% increased risk of mucinous ovarian carcinomas $(95 \% \mathrm{CI}$, $1.01,1.12, \mathrm{n}=581$ ) with each increase in intake of $10 \mathrm{~g} /$ day alcohol using continuous estimates obtained from authors of primary reports [37]. A more recent meta-analysis of 27 observational studies found no overall association of moderate or heavy drinking, but found an inverse trend with endometrioid ovarian carcinoma from three studies reporting associations by histology [38]. Two other reports summarized the epidemiologic evidence of the relation between alcohol and ovarian carcinoma descriptively [39] and as a systematic review [27]. Reviews or meta-analytic techniques that summarize categorical data from primary investigations comparing highest to lowest intakes have several limitations, including a loss of data when intermediate intake categories are excluded, which may introduce reporting bias, a problem termed "publication bias in situ" [40]. Additionally, primary studies differ in their adjustment for important confounders, in whether they distinguish invasive cancers from borderline tumors, which differ genetically, molecularly and clinically [41,42], and in whether they reported associations separately by histologic type. These differences challenge the ability to synthesize published findings. To circumvent these limitations, we conducted a large pooled analysis of original data from 12 studies participating in the Ovarian Cancer Association Consortium (OCAC).

\section{Methods}

\section{Study subjects}

Twelve studies of ovarian cancer that contributed data are described in Table 1. All studies used populationbased ascertainment methods for identifying eligible cases and controls and most studies matched cases to controls on age or age and region of residence. Eight studies were from the United States or Canada (CON [43], DOV [44], HAW [45], HOP [46], NCO [47,48], NEC [49,50], NJO [51,52] and SON [53]), three were from Europe (GER [54], MAL [55-57] and POL [58]) and one was from Australia (AUS [59]). Informed consent was obtained from participating subjects in each of the individual studies, and local human research investigations committees approved each study.

\section{Alcohol assessment and covariate data collection}

The unit of analysis for alcohol consumption was average daily grams of alcohol intake (g/d). Daily alcohol intake was estimated using validated food frequency questionnaires (FFQs) in AUS [60], DOV [61], HAW [62], MAL, NEC [63], NJO [51] and SON [53]. The exposure period was the year preceding recruitment (AUS, HAW, MAL, NEC, NJO and SON) or the time period approximately four years before the reference date (DOV). The remaining studies did not use FFQs but embedded questions regarding alcohol intake in risk factor questionnaires (CON [43], GER, HOP [34], NCO and POL). The exposure period for these studies was habitual regular drinking at the reference date (HOP) or the time period approximately five years before the reference date (CON, GER, NCO and POL). Daily alcohol intake for all studies was calculated by summing the product of the frequency of consumption of a specified serving of alcoholic beverage (beer, wine and liquor) by the alcohol content of that beverage using national estimates of alcohol content for that country. Total alcohol was estimated as the sum of alcohol intake across all alcoholic beverage types and submitted for pooled analysis. A subset of studies (AUS, CON, DOV, HAW, HOP and NEC) provided information for white and red wine separately.

Key clinical, demographic and questionnaire data on study subjects were merged into a common dataset and included case-control status, ethnicity/race, tumor behavior and histology, age at diagnosis (or comparable reference date for controls), history of prior cancers, current/former/never smoking status, menopausal status, oral contraceptive use, tubal ligation, endometriosis, hysterectomy, family history of breast or ovarian cancer 


\begin{tabular}{|c|c|c|c|c|c|c|c|c|c|c|c|c|}
\hline \multirow{2}{*}{$\begin{array}{l}\text { Study } \\
\text { acronym }\end{array}$} & \multirow[t]{2}{*}{ Study name } & \multirow{2}{*}{$\underset{n}{\text { Controls, }}$} & \multicolumn{6}{|c|}{ Cases, $\mathbf{n}$} & \multirow{2}{*}{$\begin{array}{l}\text { White non- } \\
\text { Hispanic \% }\end{array}$} & \multirow{2}{*}{$\begin{array}{l}\text { Carcinoma cases } \\
\text { with grade } \\
\text { information } \% \dagger\end{array}$} & \multirow{2}{*}{$\begin{array}{l}\text { Recruitment } \\
\text { year and } \\
\text { location }\end{array}$} & \multirow[t]{2}{*}{ Matching variables $\neq$} \\
\hline & & & $\begin{array}{l}\text { Border- } \\
\text { line }\end{array}$ & $\begin{array}{l}\text { All } \\
\text { carcinomas§ }\end{array}$ & Serous & $\begin{array}{l}\text { Muc- } \\
\text { inous }\end{array}$ & $\begin{array}{l}\text { Endo- } \\
\text { metrioid }\end{array}$ & $\begin{array}{l}\text { Clear } \\
\text { Cell } \\
\end{array}$ & & & & \\
\hline AUS [59] & $\begin{array}{l}\text { AOCS (Australian Ovarian Cancer } \\
\text { Study) and ACS (Australian } \\
\text { Cancer Study - Ovarian Cancer) }\end{array}$ & 1,333 & 259 & 882 & 537 & 39 & 106 & 71 & 93.3 & 92.8 & $\begin{array}{l}\text { 2002-2006; } \\
\text { Australia }\end{array}$ & $\begin{array}{l}\text { State of residence and 5- } \\
\text { year age groups }\end{array}$ \\
\hline CON [43] & $\begin{array}{l}\text { CON (Connecticut Ovarian Cancer } \\
\text { Study) }\end{array}$ & 526 & 103 & 339 & 193 & 18 & 70 & 33 & 91.7 & 85.4 & $\begin{array}{l}\text { 1998-2003; } \\
\text { Connecticut, USA }\end{array}$ & $\begin{array}{l}3 \text { age strata ( } 35-49,50-64 \\
\text { and } 65-79 \text { years) }\end{array}$ \\
\hline DOV [44] & $\begin{array}{l}\text { DOVE (Diseases of the Ovary and } \\
\text { their Evaluation) }\end{array}$ & 1,116 & 189 & 483 & 269 & 20 & 81 & 31 & 90.9 & 82.7 & $\begin{array}{l}\text { 2002-2005 and } \\
\text { 2006-2009; } \\
\text { Washington, USA }\end{array}$ & $\begin{array}{l}\text { 5-year age groups, 1-year } \\
\text { calendar intervals and } \\
\text { two county strata }\end{array}$ \\
\hline GER [54] & $\begin{array}{l}\text { GOCS (German Ovarian Cancer } \\
\text { Study) }\end{array}$ & 502 & 30 & 209 & 107 & 24 & 23 & 6 & 99.9 & 100 & $\begin{array}{l}\text { 1993-1996; } \\
\text { Germany }\end{array}$ & Age and study region \\
\hline HAW [45] & $\begin{array}{l}\text { HAWAll (Hawaii Ovarian Cancer } \\
\text { Study) }\end{array}$ & 1,100 & 97 & 384 & 176 & 42 & 68 & 50 & 31.9 & 91.3 & $\begin{array}{l}\text { 1993-2008; } \\
\text { Hawaii, USA }\end{array}$ & $\begin{array}{l}\text { 5-year age groups and } \\
\text { race }\end{array}$ \\
\hline HOP [46] & $\begin{array}{l}\text { HOPE (Hormones and Ovarian } \\
\text { Cancer Prediction Study) }\end{array}$ & 1,365 & 76 & 530 & 289 & 27 & 71 & 46 & 96.0 & 94.1 & $\begin{array}{l}\text { 2003-2009; } \\
\text { Pennsylvania, USA }\end{array}$ & $\begin{array}{l}\text { 5-year age groups and } \\
\text { area code plus } 3 \\
\text { number prefix }\end{array}$ \\
\hline $\begin{array}{l}\text { MAL [55- } \\
57]\end{array}$ & $\begin{array}{l}\text { MALOVA (Malignant Ovarian } \\
\text { Cancer Study) }\end{array}$ & 908 & 115 & 267 & 157 & 30 & 41 & 21 & 100 & 93.9 & $\begin{array}{l}\text { 1994-1999; } \\
\text { Denmark }\end{array}$ & 5-year age groups \\
\hline $\begin{array}{l}\mathrm{NCO} \\
{[47,48]}\end{array}$ & $\begin{array}{l}\text { NCOCS (North Carolina Ovarian } \\
\text { Cancer Study) }\end{array}$ & 979 & 212 & 777 & 429 & 44 & 126 & 82 & 80.9 & 100 & $\begin{array}{l}\text { 1999-2008; North } \\
\text { Carolina, USA }\end{array}$ & $\begin{array}{l}\text { 5-year age groups and } \\
\text { race }\end{array}$ \\
\hline $\begin{array}{l}\text { NEC } \\
{[49,50]}\end{array}$ & $\begin{array}{l}\text { NECC (New England-based Case- } \\
\text { Control Study) }\end{array}$ & 1,109 & 274 & 707 & 386 & 47 & 152 & 96 & 96.3 & 100 & $\begin{array}{l}\text { 1992-1997 and } \\
\text { 1998-2003; New } \\
\text { England, USA }\end{array}$ & $\begin{array}{l}\text { 5-year age groups and } \\
\text { region of residence }\end{array}$ \\
\hline $\begin{array}{l}\text { NJO } \\
{[51,52]}\end{array}$ & $\begin{array}{l}\text { NJOCS (New Jersey Ovarian } \\
\text { Cancer Study) }\end{array}$ & 277 & 0 & 183 & 104 & 7 & 30 & 24 & 87.6 & 87.2 & $\begin{array}{l}\text { 2002-2008; New } \\
\text { Jersey, USA }\end{array}$ & None \\
\hline POL [58] & $\begin{array}{l}\text { POL (Polish Ovarian Cancer } \\
\text { Control Study) }\end{array}$ & 601 & 18 & 236 & 101 & 25 & 52 & 13 & 100 & 66.3 & $\begin{array}{l}\text { 2000-2003; } \\
\text { Poland }\end{array}$ & $\begin{array}{l}\text { 5-year age groups and } \\
\text { study center }\end{array}$ \\
\hline SON [53] & $\begin{array}{l}\text { SON (Southern Ontario Study of } \\
\text { Reproduction, Diet and Health) }\end{array}$ & 542 & 82 & 345 & 200 & 38 & 65 & 28 & 98.3 & 0 & $\begin{array}{l}\text { 1989-1992; } \\
\text { Southern Ontario }\end{array}$ & $\begin{array}{l}3 \text { age strata ( } 35-49,50-64 \\
\text { and } 65-79 \text { years) }\end{array}$ \\
\hline Totals & & 10,358 & 1,455 & 5,342 & 2,948 & 361 & 885 & 501 & 87.7 & 84.86 & & \\
\hline
\end{tabular}

* White non-Hispanic subjects as a percentage of all race-ethnicities enrolled in each study.

† Percentages reflect grade available for serous, mucinous and endometrioid carcinomas and for which we applied the algorithm to reduce histologic misclassification (see Methods).

₹ All studies except GER used frequency matching.

$\S$ Includes the epithelial histologic types: serous, mucinous, endometrioid, clear cell, mixed epithelial, transitional cell, squamous cell, and undifferentiated. 
in first-degree relatives, parity, age at last parturition, interview year, age at menarche, body mass index (BMI) and study site. Total energy intake was obtained from studies that collected dietary information using FFQs (AUS, DOV, HAW, NEC, NJO and SON). The data were checked for consistency and completeness and discrepancies were followed-up with individual study investigators.

We excluded from analyses subjects with nonepithelial ovarian tumors, prior histories of cancer other than non-melanoma skin cancer or subjects with missing information for total alcohol intake. Data were available from 5,342 cases of incident ovarian carcinoma, 1,455 women with incident ovarian borderline tumors and 10,358 controls (Table 1).

\section{Statistical analysis}

The studies were combined into a single dataset for analysis. Alcohol intake categories were derived in increments of one standard drink ( $\mathrm{g}$ ethanol content) consumed daily: alcohol from any source (10 g); $12 \mathrm{oz}$ beer (12.2 g), $4 \mathrm{oz}$ wine (10.5 g) and $1 \mathrm{oz}$ liquor (9.5 g). Primary analyses evaluated associations between alcohol intake and risk of ovarian carcinoma (excluding borderline tumors) using unconditional logistic regression to estimate odds ratios (OR) and 95\% confidence intervals (CI). Trends in risk were evaluated by modeling the ordinal variable representing the category values of alcohol intake (e.g., 1, 2, 3) in the regression models with 1 degree-of-freedom [64]. Statistical heterogeneity in ORs across studies was evaluated using the likelihood ratio test comparing models with and without an interaction term between alcohol intake and study site. To describe further the degree of statistical heterogeneity, we estimated $I^{2}$, the between-group variance [65], which describes the proportion of total variation in estimates of the ORs due to the heterogeneity between groups of studies. We estimated $I^{2}$ to evaluate statistical heterogeneity between studies defined by their continent of origin. Groups of studies with statistically homogeneous ORs have an $I^{2}$ value of zero.

All models were adjusted for the known or potential confounders footnoted in the tables. Risk models associated with total alcohol intake did not include other alcoholic beverage types. Risk models associated with beer, wine or liquor intake included all three beverage types and were thus adjusted for each other. Risk models associated with white or red wine intake included both types of wine as well as beer and liquor intake. To account for potential heterogeneity of summary risk estimates across studies, all models included interaction terms between every non-alcohol covariate and study site and are thus equivalent to fixed-effects meta-analyses, although the exclusion of these terms did not alter the risk estimates appreciably (data not shown). In addition, among a subset of studies, primary analyses were also adjusted for total energy intake, excluding subjects with extreme total energy values as previously described [66] and using the residual method [67], in order to evaluate the extent of confounding from this variable.

For the 12 studies combined, we simultaneously modeled the risk of each of five histologic types of ovarian carcinoma (high-grade serous, low-grade serous, mucinous, endometrioid and clear cell) and two of the four main types of borderline tumors with sufficient numbers for analysis (serous and mucinous) using polytomous logistic regression [68]. Risk models were adjusted for all covariates but excluded the interactions between nonalcohol covariates and study site to ease statistical computation. Statistical heterogeneity of the alcohol-ovarian tumor histology associations was tested separately for the carcinomas and the borderline tumors and was evaluated using the type 3 analysis of effects with degreesof-freedom equal to the number of response levels minus one times the number of exposure levels minus one [68]. For these models, we incorporated considerations from the contemporary pathology literature to refine risk associations in the analyses of histologic type, as implemented previously [69]. Specifically, others have shown that an appreciable proportion of grade 3 mucinous ovarian carcinomas are, in fact, metastatic from the gastrointestinal tract [70], up to one-third of endometrioid ovarian carcinomas are high-grade serous ovarian carcinomas [71,72] and approximately 3\% of epithelial ovarian carcinomas are low-grade serous [71,72]. We, therefore, re-assigned histologic type according to the expected distributions of histology combined with grade observed from large population-based series [71,72] as follows. Endometrioid carcinomas were re-classified as high-grade serous carcinomas if their grade was $\geq G 3$, mucinous carcinomas were assumed to be metastatic and excluded from analysis if $\geq G 3$, and serous histology was re-classified as either low-grade serous carcinomas (G1) or high-grade serous carcinomas $(\geq \mathrm{G} 2)$.

Because of the reported association between smoking and ovarian carcinoma and, particularly for mucinous ovarian carcinoma and mucinous borderline tumors $[22,24,25]$, statistical interaction was evaluated using the likelihood ratio test comparing models with and without an interaction term for the categorical forms of alcohol intake and smoking status (never, current and former). We also performed stratified analyses of alcohol intake across categories of smoking status. Potential modification of the alcohol-ovarian carcinoma association by other variables was examined using a similar approach.

Statistical tests were two-sided and implemented with SAS (SAS Institute, Cary, NC, Version 9.1). Funnel plots representing the study-specific and combined data estimates were derived from the logistic regression models as described above. 
Table 2 Association between consumers of alcoholic beverages and ovarian carcinoma, OCAC studies

\begin{tabular}{|c|c|c|}
\hline Intake/d & $\mathrm{Ca} / \mathrm{Co}$ & OR $(95 \% \mathrm{CI})$ \\
\hline Total alcohol & $5,342 / 10,358$ & \\
\hline None & 2,269/4,296 & 1.0 (Ref) \\
\hline Up to 1 drink* & $2,074 / 3,928$ & $0.94(0.85-1.03)$ \\
\hline 1-2 drinks & $560 / 1,112$ & $0.97(0.85-1.11)$ \\
\hline 2-3 drinks & $192 / 400$ & $0.91(0.74-1.11)$ \\
\hline$>3$ drinks & $247 / 622$ & $0.92(0.76-1.10)$ \\
\hline$P$ trend & & 0.27 \\
\hline \multicolumn{3}{|l|}{ Beer $†$} \\
\hline None & $4,016 / 7,472$ & 1.0 (Ref) \\
\hline Up to $12 \mathrm{oz}$ & $1,179 / 2,570$ & $0.92(0.83-1.02)$ \\
\hline$>12 \mathrm{oz}$ & $147 / 315$ & $1.09(0.86-1.37)$ \\
\hline$P$ trend & & 0.43 \\
\hline \multicolumn{3}{|l|}{ Wine ${ }^{\dagger}$} \\
\hline None & $2,821 / 5,307$ & 1.0 (Ref) \\
\hline Up to 4 oz & $2,057 / 3,984$ & $0.94(0.85-1.04)$ \\
\hline 4-8 oz & $261 / 522$ & $1.00(0.83-1.20)$ \\
\hline$>8 \mathrm{oz}$ & $203 / 545$ & $0.83(0.68-1.01)$ \\
\hline$P$ trend & & 0.08 \\
\hline
\end{tabular}

White wine $\neq$

$\begin{array}{lc}\text { None } & 2,110 / 4,114 \\ \text { Up to } 4 \text { oz } & 1,053 / 2,032 \\ >4 \text { oz } & 162 / 406 \\ \text { P trend } & \end{array}$

Red wine $\ddagger$

\begin{tabular}{lcc} 
None & $2,330 / 4,548$ & 1.0 (Ref) \\
Up to 4 oz & $866 / 1,665$ & $0.92(0.81-1.05)$ \\
$>4$ oz & $129 / 336$ & $0.90(0.71-1.15)$ \\
trend & & 0.11 \\
Liquor $†$ & \\
None & $3,599 / 6,865$ & 1.0 (Ref) \\
Up to 1 oz & $1,535 / 3,061$ & $0.97(0.88-1.08)$ \\
$>1$ oz & $208 / 431$ & $1.03(0.85-1.26)$ \\
P trend & & 0.82 \\
\hline
\end{tabular}

Adjusted for age $(<40 ; 40-49 ; 50-59 ; 60-69 ; 70+$ years), smoking status (never, former, current), site (AUS, CON, DOV, GER, HAW, HOP, MAL, NCO, NEC, NJO, $\mathrm{POL}, \mathrm{SON}$ ), race/ethnicity (white nonHispanic; white Hispanic; black non Hispanic; Asian; other or unknown); menopausal status (pre/peri-menopausal; postmenopausal, unknown or missing), oral contraceptive use $(<6 \mathrm{mo}, 6-22$ mo, 23+ mo, unknown or missing), tubal ligation (yes; no; unknown or missing), endometriosis (yes; no; unknown or missing), hysterectomy (yes; no; unknown or missing), family history of breast or ovarian cancer in first-degree relatives (no; yes; unknown; no daughters or sisters), parity/age at last birth (nulliparous; $1-2$ births/age $\leq 25$ yrs at last pregnancy; $3+$ births/age $\leq 25$ yrs at last pregnancy; $1-2$ births/age $>25$ years at last pregnancy; $3+$ births/age $>25$ years at last pregnancy; yes if ever pregnant but unknown or missing age at last pregnancy age; no or unknown if ever pregnant and missing age at last pregnancy, interview year (1990-1994; 1995-1999; 2000-2004; 2005-2009; missing), age at menarche (8-10 yrs; 11 yrs; 12 yrs; 13 yrs; $14-21$ yrs; $<8$ or $\geq$ $22 \mathrm{yrs}$ ), body mass index (continuous) and education (less than high school, high school, some college, completed college or university, completed graduate or professional degree, missing). Models include interaction terms between site and each covariate except alcohol.

* 1 drink = 10 grams ethanol.

† Models are also simultaneously adjusted for consumption of beer, wine and liquor intake.

₹ White/red wine information available from AUS, CON, DOV, HAW, HOP and NEC only. Models are simultaneously adjusted for beer and liquor intake.

\section{Results}

Characteristics of included studies and participants

Table 1 describes the characteristics of the 12 case-control studies. Eighty-eight percent of the cases were white nonHispanic and $\sim 85 \%$ of the carcinomas had information on tumor grade. The distribution of alcohol intake is shown in Additional file 1: Table S1, overall and for each study separately. Overall, average daily total alcohol intake ranged from approximately one-fifth of a standard drink at the $25^{\text {th }}$ percentile to $1-2$ drinks at the $75^{\text {th }}$ percentile of the distributions. More women consumed wine than the other alcoholic beverages.

Generally, cases and controls were similar in their distributions across covariates (Additional file 1: Table S2). As expected, however, cases were more frequently postmenopausal than controls, were more likely to be nulliparous, and less likely than controls to have used oral contraceptive hormones for appreciable durations or to have had tubal ligation or a hysterectomy. The majority $(\sim 75 \%)$ of subjects were recruited in the past decade. The distribution of covariates did not differ by much among controls who consumed beer, wine or liquor except, perhaps, that fewer wine consumers were current smokers and a greater proportion of beer drinkers were pre- or peri-menopausal.

\section{Alcohol consumption and risk of ovarian carcinoma}

In multivariable-adjusted pooled analyses, total alcohol intake from any source was not associated with risk of ovarian carcinoma (consumption of $>3$ drinks per day compared to none: $\mathrm{OR}=0.92,95 \% \mathrm{CI}=0.76-1.10$, $\mathrm{P}$ trend $=0.27$; Table 2). Given the absence of a doseresponse relationship, we modeled the variable dichotomously (none, any regular consumption) (Figure 1). Adjustment for known or suspected confounders beyond age and race (Figure 1A) tended to attenuate risk associations (Figure 1B) indicating the importance of accounting for these variables in the analysis. Further adjustment for total energy had little effect (data not shown).

\section{Alcoholic beverage type and risk of ovarian carcinoma}

All studies provided information on type of alcoholic beverage consumed (beer, wine and liquor). Compared to women who reported no wine intake, we observed a statistically non-significant decreased risk associated with consumption of more than $8 \mathrm{oz} / \mathrm{d}$ of wine after adjusting 


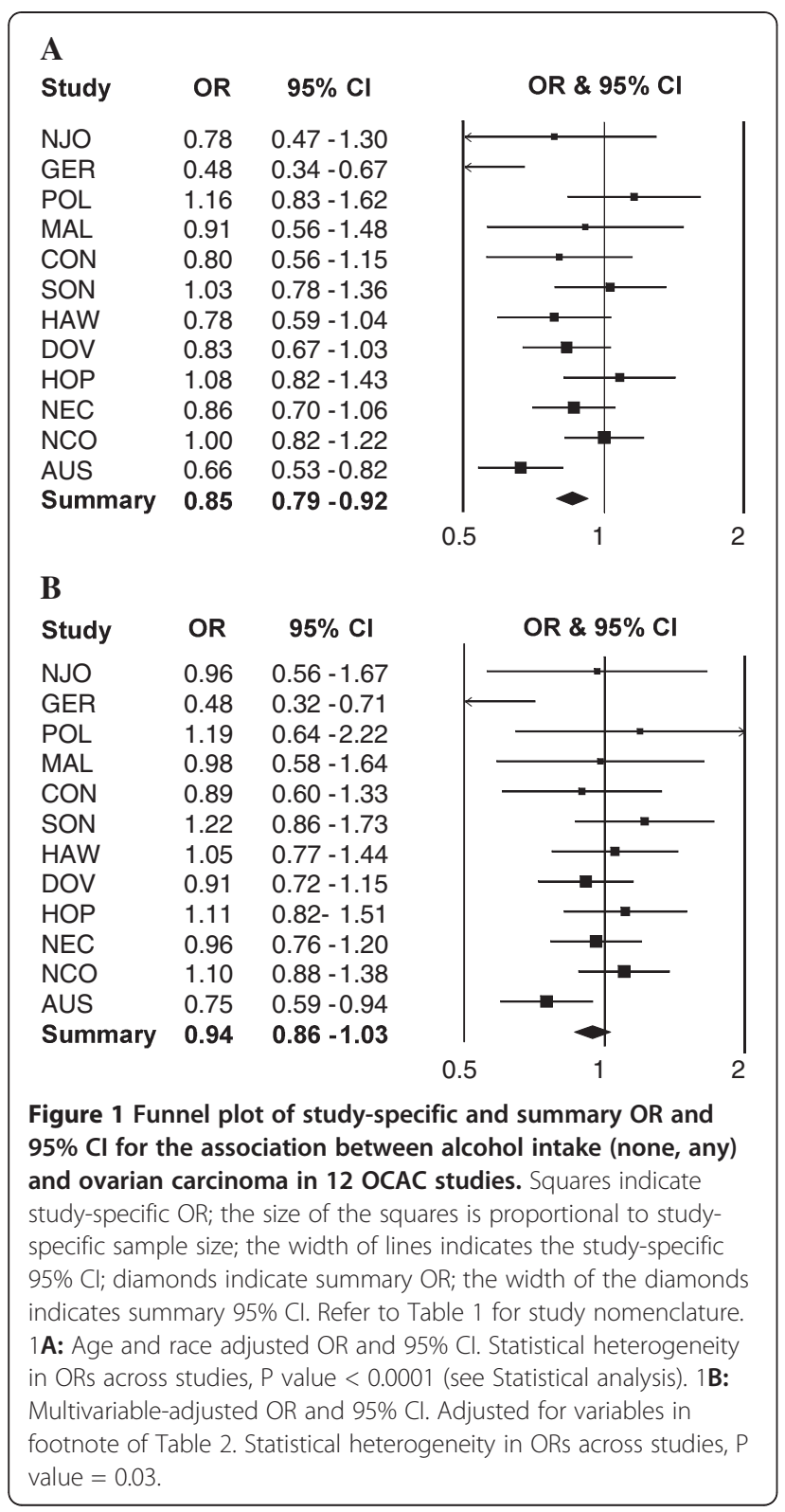

for consumption of other types of alcoholic beverage intake ( $\mathrm{OR}=0.83,95 \% \mathrm{CI}=0.68-1.01, \mathrm{P}$ trend $=0.08$; Table 2$)$. Associations did not differ by much when we restricted the analyses to those individuals who consumed only one type of alcoholic beverage (data not shown). Among a subset of studies with information on white or red wine consumed, risk associations were not statistically significant.

\section{Alcohol and ovarian tumor histologic types}

More than 3 average drinks/d of alcohol intake from any source was associated with a lower risk of endometrioid ovarian carcinoma ( $\mathrm{OR}=0.49,95 \% \mathrm{CI}=0.27-0.91)$, although this was no longer evident when the two highest intake categories were combined ( $>2$ drinks $/ \mathrm{d}$ : $\mathrm{OR}=0.85,95 \%$ $\mathrm{CI}=0.58-1.26 ; \mathrm{P}$ trend=0.45; Table 3 ). We observed a statistically significant inverse trend between consumption of wine and clear cell ovarian carcinomas with a decreased risk at higher intakes only ( $>8 \mathrm{oz} / \mathrm{d}$ : $\mathrm{OR}=0.43,95 \%$ $\mathrm{CI}=0.22-0.83 ; \mathrm{P}$ trend=0.02). This association, however, was based on 10 cases and the heterogeneity between histologic types was not statistically significant (P heterogeneity $=0.09$ ). Following combining the two highest intake categories, the association remained suggestive $(>4 \mathrm{oz} / \mathrm{d}$ : $\mathrm{OR}=0.70,95 \% \mathrm{CI}=0.47-1.03, \mathrm{P}$ trend $=0.05$; Table 3 ). A statistically non-significant increased risk was also seen between total alcohol intake over 3 average drinks/d and mucinous borderline tumors $(\mathrm{OR}=1.40,95 \% \mathrm{CI}=0.99-1.20$; $\mathrm{P}$ trend $=0.22$, Table 4 , data shown for total alcohol and wine only) but disappeared following combining the two highest intake categories $(>4 \mathrm{oz} / \mathrm{d}$ : $\mathrm{OR}=1.22,95 \% \mathrm{CI}=0.90$ 1.66, P trend $=0.42$; Table 4). Application of the pathologybased algorithm tended to shift estimates and 95\% CIs farther from the null, although there was no appreciable difference in significance of estimates when the algorithm was not implemented (Additional file 1: Table S3).

\section{Potential sources of effect modification}

The association between total alcohol intake (none, any regular consumption) and risk of ovarian carcinoma varied somewhat across studies following multivariable adjustment (Figure 1B, P interaction=0.03); the source of heterogeneity was within the three European studies when evaluated by continent of study origin (withingroup heterogeneity: Europe, $I^{2}=75 \%$; North America, $I^{2}=0 \%$ ). The association between wine intake (none, any regular consumption) and risk of ovarian carcinoma also varied across studies following multivariable adjustment ( $\mathrm{P}$ interaction $=0.01)$ and significant heterogeneity was again observed within the European studies $\left(I^{2}=81 \%\right)$. Within North American studies, the estimates for wine intake were statistically homogeneous for ovarian carcinoma overall (OR, 0.99; 95\% CI, 0.89-1.10; $I^{2}=0 \%$ ). We evaluated whether the decreased risk observed between wine intake and clear cell carcinomas (Table 3) was influenced by the variability within European studies by excluding the three European studies. The association between consumption of $>8 \mathrm{oz} / \mathrm{d}$ wine and clear cell ovarian carcinomas remained significant $(\mathrm{OR}=0.48,95 \%$ $\mathrm{CI}=0.25-0.95$; $\mathrm{P}$ trend=0.03; 10 cases). Alcohol, in general, has been reported to reduce cellular proliferation by influencing the insulin and insulin-like growth factor (IGF) pathways [73,74], and these pathways have been implicated in the early development and prognosis of clear cell carcinoma types [75-78]. Because obesity is associated with impaired insulin sensitivity [74], we tested the trend association of alcohol or wine intake with histologic types stratified by BMI $\left(<30\right.$ vs $\left.\geq 30 \mathrm{~kg} / \mathrm{m}^{2}\right)$. There was no clear effect modification by BMI among any of the histologic types for total alcohol intake (data not 
Table 3 Association between total alcohol and wine intake and histological types* of ovarian carcinoma, OCAC studies

\begin{tabular}{|c|c|c|c|c|c|c|c|c|c|c|c|c|}
\hline \multirow[t]{2}{*}{ Intake/d } & \multirow{2}{*}{$\begin{array}{c}\text { Controls } \\
\mathrm{N}=10,358 \\
\text { Co }\end{array}$} & \multicolumn{2}{|c|}{$\begin{array}{c}\text { High-Grade Serous } \\
N=2,580\end{array}$} & \multicolumn{2}{|c|}{$\begin{array}{l}\text { Mucinous } \\
\mathrm{N}=245\end{array}$} & \multicolumn{2}{|c|}{$\begin{array}{l}\text { Endometrioid } \\
\mathrm{N}=506\end{array}$} & \multicolumn{2}{|c|}{ Clear Cell N=501 } & \multicolumn{2}{|c|}{$\begin{array}{c}\text { Low-Grade Serous } \\
\mathrm{N}=198\end{array}$} & \multirow[b]{2}{*}{$P$ valuet } \\
\hline & & $\mathrm{Ca}$ & OR $(95 \% \mathrm{Cl})$ & $\mathrm{Ca}$ & OR $(95 \% \mathrm{Cl})$ & $\mathrm{Ca}$ & OR $(95 \% \mathrm{Cl})$ & $\mathrm{Ca}$ & OR $(95 \% \mathrm{Cl})$ & $\mathrm{Ca}$ & OR $(95 \% \mathrm{Cl})$ & \\
\hline \multicolumn{13}{|l|}{ Total alcohol ₹ } \\
\hline None & 4,296 & 1,060 & 1.0 (Ref) & 98 & 1.0 (Ref) & 214 & 1.0 (Ref) & 223 & 1.0 (Ref) & 61 & 1.0 (Ref) & \\
\hline Up to 1 drink & 3,928 & 1,029 & $0.95(0.84-1.07)$ & 97 & $1.08(0.76-1.52)$ & 207 & $0.97(0.76-1.23)$ & 188 & $0.84(0.66-1.07)$ & 90 & $0.95(0.65-1.38)$ & \\
\hline 1-2 drinks & 1,112 & 282 & $0.97(0.83-1.15)$ & 26 & $1.08(0.66-1.75)$ & 50 & $0.96(0.68-1.36)$ & 53 & $0.97(0.69-1.37)$ & 29 & $1.28(0.78-2.11)$ & \\
\hline 2-3 drinks & 400 & 79 & $0.78(0.60-1.02)$ & 11 & $1.36(0.69-2.67)$ & 23 & $1.36(0.85-2.19)$ & 17 & $0.96(0.56-1.63)$ & 8 & $0.98(0.45-2.13)$ & \\
\hline$>3$ drinks & 622 & 130 & $0.96(0.77-1.20)$ & 13 & $0.98(0.52-1.82)$ & 12 & $0.49(0.27-0.91)$ & 20 & $0.82(0.50-1.34)$ & 10 & $1.12(0.55-2.29)$ & \\
\hline$P$ trend & & & 0.31 & & 0.71 & & 0.25 & & 0.50 & & 0.54 & 0.67 \\
\hline$>2$ drinks§ & 1,022 & 209 & $0.88(0.74-1.06)$ & 24 & $1.12(0.69-1.83)$ & 35 & $0.85(0.58-1.26)$ & 37 & $0.88(0.60-1.30)$ & 18 & $1.05(0.59-1.86)$ & \\
\hline $\mathrm{P}$ trend $\S$ & & & 0.24 & & 0.62 & & 0.45 & & 0.52 & & 0.53 & 0.71 \\
\hline \multicolumn{13}{|l|}{ Wine } \\
\hline None & 5,307 & 1,316 & 1.0 (Ref) & 128 & 1.0 (Ref) & 263 & 1.0 (Ref) & 272 & 1.0 (Ref) & 81 & 1.0 (Ref) & \\
\hline Up to $4 \mathrm{oz}$ & 3,984 & 1,022 & $0.93(0.83-1.04)$ & 103 & $1.12(0.81-1.54)$ & 206 & $0.96(0.77-1.21)$ & 195 & $0.87(0.69-1.09)$ & 91 & $0.94(0.66-1.34)$ & \\
\hline $4-8 \mathrm{oz}$ & 522 & 129 & $0.93(0.75-1.16)$ & 10 & $1.03(0.52-2.04)$ & 22 & $0.98(0.61-1.58)$ & 24 & $0.95(0.60-1.50)$ & 13 & $1.33(0.70-2.50)$ & \\
\hline$>8 \mathrm{oz}$ & 545 & 113 & $0.86(0.68-1.09)$ & 4 & $0.39(0.14-1.09)$ & 15 & $0.68(0.39-1.20)$ & 10 & $0.43(0.22-0.83)$ & 13 & $1.35(0.71-2.56)$ & \\
\hline$P$ trend & & & 0.13 & & 0.32 & & 0.29 & & 0.02 & & 0.34 & 0.09 \\
\hline$>4 \mathrm{oz} \S$ & 1,067 & 242 & $0.89(0.75-1.06)$ & 14 & $0.70(0.39-1.27)$ & 37 & $0.84(0.57-1.23)$ & 34 & $0.70(0.47-1.03)$ & 26 & $1.34(0.81-2.20)$ & \\
\hline$P$ trend $\S$ & & & 0.13 & & 0.61 & & 0.41 & & 0.05 & & 0.44 & 0.25 \\
\hline \multicolumn{13}{|c|}{$\begin{array}{l}\text { Adjusted for age (<40; 40-49; 50-59; 60-69; 70+ years), smoking status (never, former, current), site (AUS, } \\
\text { black non Hispanic; Asian; other or unknown); menopausal status (pre/peri-menopausal; postmenopausal } \\
\text { (yes; no; unknown or missing), endometriosis (yes; no; unknown or missing), hysterectomy (yes; no; unkn } \\
\text { daughters or sisters), parity/age at last birth (nulliparous; } 1-2 \text { births/age } \leq 25 \text { yrs at last pregnancy; } 3+\text { birt } \\
\text { pregnancy; yes if ever pregnant but unknown or missing age at last pregnancy age; no or unknown if ev } \\
\text { missing), age at menarche (8-10 yrs; } 11 \mathrm{yrs;} ; 12 \mathrm{yrs} ; 13 \text { yrs; } 14-21 \text { yrs; }<8 \text { or } \geq 22 \text { yrs), body mass index (co } \\
\text { completed graduate or professional degree, missing). } \\
\text { * Cases restricted to samples with information on grade for serous, mucinous and endometrioid histolog } \\
\dagger P \text { for tumor heterogeneity derived from testing the trend variable for alcohol or wine intake in polytom } \\
\neq 1 \text { drink }=10 \text { grams ethanol. } \\
\S \text { Risk estimates and P trend values are from models that collapse the two highest intake categories. } \\
\text { Models are also simultaneously adjusted for consumption of beer and liquor intake. }\end{array}$} \\
\hline
\end{tabular}


Table 4 Association between total alcohol and wine intake and ovarian borderline tumors, OCAC studies

\begin{tabular}{|c|c|c|c|c|c|c|}
\hline \multirow{2}{*}{$\begin{array}{l}\text { Intake/d } \\
\text { Total alcohol * }\end{array}$} & \multirow[t]{2}{*}{ Controls $\mathrm{N}=10,358$} & \multicolumn{2}{|c|}{ Serous borderline $\mathrm{N}=\mathbf{8 1 8}$} & \multicolumn{2}{|c|}{ Mucinous borderline $\mathrm{N}=561$} & \multirow[b]{2}{*}{$P$ valuet } \\
\hline & & $\mathrm{Ca}$ & OR $(95 \% \mathrm{Cl})$ & $\mathrm{Ca}$ & OR $(95 \% \mathrm{Cl})$ & \\
\hline None & 4,296 & 297 & 1.0 (Ref) & 181 & 1.0 (Ref) & \\
\hline Up to 1 drink & 3,928 & 349 & $0.87(0.72-1.05)$ & 245 & $0.95(0.76-1.20)$ & \\
\hline $1-2$ drinks & 1,112 & 86 & $0.91(0.69-1.20)$ & 59 & $0.86(0.62-1.20)$ & \\
\hline $2-3$ drinks & 400 & 32 & $1.04(0.69-1.56)$ & 23 & $0.94(0.58-1.51)$ & \\
\hline$>3$ drinks & 622 & 54 & $1.19(0.86-1.66)$ & 53 & $1.40(0.99-1.20)$ & \\
\hline$P$ trend & & & 0.45 & & 0.22 & 0.39 \\
\hline$>2$ drinks $\S$ & 1,022 & 86 & $1.13(0.86-1.49)$ & 76 & $1.22(0.90-1.66)$ & \\
\hline$P$ trend $\S$ & & & 0.63 & & 0.42 & 0.67 \\
\hline \multicolumn{7}{|l|}{ Wine } \\
\hline None & 5,307 & 405 & 1.0 (Ref) & 263 & 1.0 (Ref) & \\
\hline Up to $4 \mathrm{oz}$ & 3,984 & 336 & $0.89(0.74-1.06)$ & 236 & $0.89(0.72-1.10)$ & \\
\hline $4-8$ oz & 522 & 38 & $0.99(0.68-1.43)$ & 26 & $0.88(0.57-1.36)$ & \\
\hline$>8 \mathrm{oz}$ & 545 & 39 & $0.99(0.69-1.44)$ & 36 & $1.03(0.69-1.52)$ & \\
\hline$P$ trend & & & 0.66 & & 0.72 & 0.87 \\
\hline$>4 \mathrm{oz} \S$ & 1,067 & 77 & $0.99(0.75-1.31)$ & 62 & $0.96(0.70-1.31)$ & \\
\hline$P$ trend $\S$ & & & 0.52 & & 0.52 & 0.69 \\
\hline
\end{tabular}

Adjusted for age (<40; 40-49; 50-59; 60-69; 70+ years), smoking status (never, former, current), site (AUS, CON, DOV, GER, HAW, HOP, MAL, NCO, NEC, NJO, POL, SON), race/ethnicity (white nonHispanic; white Hispanic; black non Hispanic; Asian; other or unknown); menopausal status (pre/peri-menopausal; postmenopausal, unknown or missing), oral contraceptive use ( $<6 \mathrm{mo}, 6-22 \mathrm{mo}, 23+\mathrm{mo}$, unknown or missing), tubal ligation (yes; no; unknown or missing), endometriosis (yes; no; unknown or missing), hysterectomy (yes; no; unknown or missing), family history of breast or ovarian cancer in first-degree relatives (no; yes; unknown; no daughters or sisters), parity/age at last birth (nulliparous; $1-2$ births/age $\leq 25$ yrs at last pregnancy; $3+$ births/age $\leq 25$ yrs at last pregnancy; $1-2$ births/age $>25$ years at last pregnancy; $3+$ births/age $>25$ years at last pregnancy; yes if ever pregnant but unknown or missing age at last pregnancy age; no or unknown if ever pregnant and missing age at last pregnancy, interview year (1990-1994; 1995-1999; 2000-2004; 2005-2009; missing), age at menarche (8-10 yrs; 11 yrs; 12 yrs; 13 yrs; $14-21$ yrs; $<8$ or $\geq 22$ yrs), body mass index (continuous) and education (less than high school, high school, some college, completed college or university, completed graduate or professional degree, missing). Wine consumption was additionally adjusted for other alcoholic beverage types. Models include interaction terms between site and each covariate except alcohol.

* 1 drink = 10 grams ethanol.

† $P$ for tumor heterogeneity derived from testing the trend variable for alcohol or wine intake in polytomous regression models with 2 df (see Statistical analysis). $\S$ Risk estimates and $\mathrm{P}$ trend values are from models that collapse the two highest intake categories.

Models are also simultaneously adjusted for consumption of beer and liquor intake.

shown), and suggestive decreased risks for wine intake at lower BMI for both clear cell carcinomas (BMI $<30 \mathrm{~kg} / \mathrm{m}^{2}$ : $\mathrm{OR}=0.83,95 \% \mathrm{CI}=0.69-1.00 ; \mathrm{n}=382$ cases vs $\mathrm{BMI} \geq 30 \mathrm{~kg} /$ $\mathrm{m}^{2}: \mathrm{OR}=0.79,95 \% \mathrm{CI}=0.53-1.18 ; \mathrm{n}=119$ cases $)$ and highgrade serous carcinomas $\left(B M I<30 \mathrm{~kg} / \mathrm{m}^{2}\right.$ : $\mathrm{OR}=0.90,95 \%$ $\mathrm{CI}=0.83-0.98 ; \mathrm{n}=2,052$ cases vs $\mathrm{BMI} \geq 30 \mathrm{~kg} / \mathrm{m}^{2}: \mathrm{OR}=1.17$, 95\% $\mathrm{CI}=0.96-1.42 ; \mathrm{n}=528$ cases). Smoking status did not significantly modify the association between ovarian carcinoma and total alcohol intake ( $\mathrm{P}$ interaction $=0.11$ ) or wine intake ( $\mathrm{P}$ interaction $=0.97$ ) (Additional file 1: Table S4) or between mucinous borderline tumors and total alcohol intake (data not shown). None of the other covariates statistically modified the alcohol- or wineovarian carcinoma association including race/ethnicity (P interactions $\geq 0.22$ ) (data not shown).

\section{Discussion}

While current guidelines for cancer prevention restrict alcohol drinking for women to no more than 1 drink per day [79], we found no evidence that recent moderate alcohol drinking increased overall ovarian carcinoma risk.
Although there was some indication of effect modification by cell type, the statistical evidence was weak. This is the largest study to date to perform this evaluation quantitatively across the five types of ovarian carcinomas and the two groups of borderline ovarian tumors using individual-level data on alcohol intake.

Various oncogenic mechanisms of alcohol are well documented [80]. Although the evidence is convincing that alcohol is a risk factor for cancers of the breast and several cancers of the gastrointestinal tract [81], it has been equivocal for ovarian cancer [17,26-33]. Overall, our investigation adds to the evidence that recent moderate alcohol consumption is not significantly associated with ovarian carcinoma. A number of design and analytic factors can lead to disparate findings across studies. For example, heterogeneity of risk estimates were observed in European studies, a finding also reported by others [38]. The type and range of alcohol intake varies considerably across European countries and should be interpreted carefully when data are pooled or evaluated meta-analytically across continents. 
Previous studies reported decreased risk from wine intake $[26,27,31,82]$, although most associations were not statistically significant. The most widely reported constituents in wine are the polyphenols, including resveratrol, which derive mainly from the aerial tissues (grape skin) because their biosynthesis is stimulated by light [83]. Numerous anticarcinogenic properties of the polyphenols have been proposed [84]. A potentially interesting finding in the current study is the association between higher recent intakes of wine with decreased risk of clear cell ovarian carcinoma. The association persisted following exclusion of the European studies. A decreased risk from wine, but not beer or liquor, intake was also found among women in a pooled analysis of 12 prospective studies of renal cell carcinoma [85]. Clear cell ovarian carcinomas share similar features with clear cell renal cell carcinomas [86-88] and it has been suggested that moderate alcohol intake may improve insulin sensitivity and regulate related pathways $[73,74]$ that are implicated in the etiology of these carcinomas [75-78]. We observed suggestive decreased risks of wine intake among nonobese women for clear cell and high-grade serous ovarian carcinomas; however, we cannot exclude the possibility that these findings are due to chance.

Several key non-genetic risk factors for ovarian cancer were reported in the early 1990s, when studies established decreased risks associated with oral contraceptive use $[10,11]$, parity $[12,13]$ and breast-feeding [12]. Using our consortium data, we recently reported that endometriosis was associated with increased risk of endometrioid and clear cell ovarian carcinomas [23]. However, few modifiable risk factors for ovarian cancers have been found. Perhaps the only lifestyle factor that is most consistently associated with modified risk of ovarian cancers is smoking, which is associated with an increased risk of both mucinous ovarian carcinoma and mucinous borderline tumors [24,25]. This emphasizes the importance of, and the need for more, pooled analyses of individual-level data that are harmonized carefully across different studies through collaborations within consortia, such as OCAC. Clearly, the research community struggles to understand the causes of the majority of these elusive and deadly cancers.

The strengths of this investigation include the analysis of individual-level data from a large sample as well as evaluation of higher levels of intakes ( $>3$ drinks/d) and the standardized method of alcohol analysis, which allowed us to quantify risk associations based on average daily grams of alcohol intake. Although we attempted to reduce potential misclassification of histologic type by applying a pathology-based algorithm, the associations were not appreciably different if the algorithm was not implemented, unlike previous analyses for other exposures where implementation of the algorithm appeared to refine those associations [69]. The large sample of histologic types permitted evaluation of a wider range of alcohol intake, particularly total alcohol and wine intake. While a potential limitation of all case-control studies is recall and selection bias, our pooled estimates are in agreement with other reports [36,38]. Furthermore, although our findings relating moderate alcohol intake near the time of diagnosis indicated no association with ovarian carcinoma, it is possible that alcohol intake at other points in the life cycle may influence risk, given the long latency period estimated for these cancers [89].

\section{Conclusions}

In conclusion, the results of this investigation do not support an association between recent moderate total alcohol intake and ovarian carcinoma overall. The findings do not strongly support variation in risk associated with specific histologic types. Understanding the modifiable causes of these deadly cancers through rigorous consortium analyses remains a priority for the research community.

\section{Additional file}

Additional file 1: Table S1. Alcohol intake distributions across study sites by case status, OCAC studies. Table S2. Distribution of covariates among cases and controls and among beer, wine and liquor consumers, OCAC studies. Table S3. Association between total alcohol and wine intake and histological types of ovarian carcinoma (original histological assignment), OCAC studies. Table S4. Association between total alcohol and wine intake and ovarian carcinoma, stratified by smoking, OCAC studies.

\section{Competing interests}

The authors declare that they have no competing interests.

\section{Authors' contributions}

LEK conceived the study design, performed the statistical analysis and drafted the manuscript; LEK, EVB, KLT, MAR, LAB, JAD, RBN, M Köbel, SHO, HY, PMW, JMS, MTG and HAR interpreted the data; EVB, KLT, MAR, LAB, JAD, RBN, SKK, JCC, GL, PJT, MEC, KM, RE, CB, AJ, EH, DWC, AFV, SHO, M King, UC, JL, MGC, HY, PMW, JMS, MTG and HAR coordinated contributing studies and provided data; All authors contributed to, and approved, the final manuscript version.

\section{Acknowledgements}

LEK is supported by a Canadian Institutes of Health Research New Investigator award (MSH-87734). The Australian Ovarian Cancer Study Management Group (D. Bowtell, G. Chenevix-Trench, A. deFazio, D. Gertig, A. Green, P. Webb) and ACS Investigators (A. Green, P. Parsons, N. Hayward, P. Webb, D. Whiteman) thank all the clinical and scientific collaborators (see http://www.aocstudy.org/) and the women for their contribution. PMW is supported by a Fellowship from the National Health \& Medical Research Council of Australia. The CON study was approved by the State of Connecticut Department of Public Health Human Investigation Committee. The cooperation of the 32 Connecticut hospitals, including Stamford Hospital, in allowing patient access, is gratefully acknowledged. Certain data used in this study were obtained from the Connecticut Tumor Registry in the Connecticut Department of Public Health. The CON authors assume full responsibility for analyses and interpretation of these data. The German Ovarian Cancer Study (GER) thank Ursula Eilber and Tanja Koehler for competent technical assistance. The NJO group thanks

Lorna Rodriguez, Lisa Paddock and the staff of the New Jersey State Cancer Registry and Thanusha Puvananayagam for their contribution to the study. 
The POL study thanks Drs Mark Sherman and Nicolas Wentzensen from the Division of Cancer Epidemiology and Genetics of the National Cancer Institute, USA, Drs Neonila Szeszenia-Dabrowska and Beata Peplonska of the Nofer Institute of Occupational Medicine (Lodz, Poland), Witold Zatonski of the Department of Cancer Epidemiology and Prevention, The M. Sklodowska-Curie Cancer Center and Institute of Oncology (Warsaw, Poland), and Pei Chao and Michael Stagner from Information Management Services (Sliver Spring MD, USA) for their valuable contributions to the study.

\section{Funding}

U.S. Army Medical Research and Materiel Command (DAMD17-01-1-0729), National Health \& Medical Research Council of Australia (199600, 400413), Cancer Councils of New South Wales, Victoria, Queensland, South Australia and Tasmania, Cancer Foundation of Western Australia (AUS); NIH (R01 CA074850 and R01 CA080742) (CON); NIH (R01 CA112523 and R01 CA87538) (DOV); German Federal Ministry of Education and Research, Programme of Clinical Biomedical Research (01 GB 9401); genotyping in part by the state of Baden-Württemberg through the Medical Faculty, University of Ulm (P.685); and data management by the German Cancer Research Center (GER); NIH (R01 CA58598, N01 CN-55424 and N01 PC-67001) (HAW); NIH (R01 CA 61107); research grant 9422252 from the Danish Cancer Society, Copenhagen, Denmark; and the Mermaid I project (MAL); NIH (R01 CA76016) and the Department of Defense (DAMD17-02-1-0666) (NCO); NIH (RO1 CA54419 and P50 CA105009) and Department of Defense W81XWH-10-102802 (NEC); NIH (K07 CA095666, R01 CA83918 and K22CA138563), The Cancer Institute of New Jersey (NJO); the Intramural Research Program of the National Cancer Institute (POL), and the National Health Research and Development Program of Health Canada, grant number 6613-1415-53 (SON).

\section{Author details}

'Department of Population Health Research, Alberta Health Services-Cancer Care and Departments of Medical Genetics and Oncology, University of Calgary, Calgary, AB, Canada. ${ }^{2}$ The Cancer Institute of New Jersey, Robert Wood Johnson Medical School, New Brunswick, NJ, USA. ${ }^{3}$ Obstetrics and Gynecology Epidemiology Center, Brigham and Women's Hospital, Boston, MA, USA. ${ }^{4}$ Department of Epidemiology, Harvard School of Public Health, Boston, MA, USA. ${ }^{5}$ Fred Hutchinson Cancer Research Center, Seattle, WA, USA. ${ }^{6}$ Division of Cancer Epidemiology and Genetics, National Cancer Institute, Bethesda, MD, USA. ${ }^{7}$ University of Texas School of Public Health, Houston, TX, USA. ${ }^{8}$ Danish Cancer Society Research Center, Copenhagen, Denmark. ${ }^{9}$ Gynecologic Clinic, Rigshospitalet, University of Copenhagen, Copenhagen, Denmark. ${ }^{10}$ Division of Cancer Epidemiology, German Cancer Research Center, Heidelberg, Germany. "1Department of Pathology and Laboratory Medicine, Calgary Laboratory Services, Calgary, AB, Canada. ${ }^{12}$ Cancer Research Center, University of Hawaii, Honolulu, HI, USA. ${ }^{13}$ Roswell Park Cancer Center, Buffalo, NY, USA. ${ }^{14}$ Magee Womens Research Institute, Pittsburgh, PA, USA. ${ }^{15}$ University of Pittsburgh School of Public Health, Pittsburgh, PA, USA. ${ }^{16}$ Memorial Sloan-Kettering Cancer Center, New York, NY, USA. ${ }^{17}$ Department of Cancer Epidemiology and Prevention, The M. Sklodowska-Curie Cancer Center and Institute of Oncology, Gliwice, Poland. ${ }^{18}$ Division of Genetics and Epidemiology, Institute of Cancer Research, Sutton, United Kingdom. ${ }^{19}$ The Queensland Institute of Medical Research, Locked Bag 2000 Royal Brisbane Hospital, Herston, Australia. ${ }^{20}$ Department of Community and Family Medicine and the Comprehensive Cancer Center, Duke University Medical Center, Durham, NC, USA. ${ }^{21}$ Departments of Medicine and Biomedical Sciences, Cedars-Sinai Medical Center, Los Angeles, CA, USA. ${ }^{22}$ Department of Chronic Disease Epidemiology, Yale School of Public Health, New Haven, CT, USA.

Received: 1 August 2012 Accepted: 17 January 2013

Published: 22 January 2013

\section{References}

1. Ferlay J, Shin HR, Bray F, Forman D, Mathers C, Parkin DM: Estimates of worldwide burden of cancer in 2008: GLOBOCAN 2008. Int J Cancer 2010, 127(12):2893-2917.

2. Lynch HT, Schuelke GS, Kimberling WJ, Albano WA, Lynch JF, Biscone KA, Lipkin ML, Deschner EE, Mikol YB, Sandberg AA, et al: Hereditary nonpolyposis colorectal cancer (Lynch syndromes I and II). II. Biomarker studies. Cancer 1985, 56(4):939-951.
3. Lynch HT, Conway T, Lynch J: Hereditary ovarian cancer. Pedigree studies, Part II. Canc Genet Cytogenet 1991, 53(2):161-183.

4. Boyd J, Rubin SC: Hereditary ovarian cancer: molecular genetics and clinical implications. Gynecol Oncol 1997, 64(2):196-206.

5. Narod SA, Madlensky L, Bradley L, Cole D, Tonin P, Rosen B, Risch HA: Hereditary and familial ovarian cancer in southern Ontario. Cancer 1994, 74(8):2341-2346.

6. Risch HA, McLaughlin JR, Cole DE, Rosen B, Bradley L, Kwan E, Jack E, Vesprini DJ, Kuperstein G, Abrahamson JL, et al: Prevalence and penetrance of germline BRCA1 and BRCA2 mutations in a population series of 649 women with ovarian cancer. Am J Hum Genet 2001, 68(3):700-710.

7. Song H, Ramus SJ, Tyrer J, Bolton KL, Gentry-Maharaj A, Wozniak E, Anton-Culver H, Chang-Claude J, Cramer DW, DiCioccio R, et al: A genome-wide association study identifies a new ovarian cancer susceptibility locus on 9p22.2. Nat Genet 2009, 41(9):996-1000.

8. Goode EL, Chenevix-Trench G, Song H, Ramus SJ, Notaridou M, Lawrenson K, Widschwendter M, Vierkant RA, Larson MC, Kjaer SK, et al: A genome-wide association study identifies susceptibility loci for ovarian cancer at $2 q 31$ and 8q24. Nat Genet 2010, 42(10):874-879

9. Bolton KL, Tyrer J, Song H, Ramus SJ, Notaridou M, Jones C, Sher T, Gentry-Maharaj A, Wozniak E, Tsai YY, et al: Common variants at $19 \mathrm{p} 13$ are associated with susceptibility to ovarian cancer. Nat Genet 2010, 42(10):880-884.

10. Hankinson SE, Colditz GA, Hunter DJ, Spencer TL, Rosner B, Stampfer MJ: A quantitative assessment of oral contraceptive use and risk of ovarian cancer. Obstet Gynecol 1992, 80(4):708-714.

11. The reduction in risk of ovarian cancer associated with oralcontraceptive use. The Cancer and Steroid Hormone Study of the Centers for Disease Control and the National Institute of Child Health and Human Development. N Eng/ J Med 1987, 316(11):650-655.

12. Whittemore AS, Harris R, Itnyre J: Characteristics relating to ovarian cancer risk: collaborative analysis of 12 US case-control studies. II. Invasive epithelial ovarian cancers in white women. Collaborative ovarian cancer group. Am J Epidemiol 1992, 136(10):1184-1203.

13. Risch HA, Marrett LD, Howe GR: Parity, contraception, infertility, and the risk of epithelial ovarian cancer. Am J Epidemiol 1994, 140(7):585-597.

14. Kurian AW, Balise RR, McGuire V, Whittemore AS: Histologic types of epithelial ovarian cancer: have they different risk factors? Gynecol Oncol 2005, 96(2):520-530.

15. Gertig DM, Hunter DJ, Cramer DW, Colditz GA, Speizer FE, Willett WC, Hankinson SE: Prospective study of talc use and ovarian cancer. J Natl Canc Inst 2000, 92(3):249-252.

16. Huncharek M, Geschwind JF, Kupelnick B: Perineal application of cosmetic talc and risk of invasive epithelial ovarian cancer: a meta-analysis of 11,933 subjects from sixteen observational studies. Anticancer Res 2003, 23(2C):1955-1960.

17. Kelemen LE, Sellers TA, Vierkant RA, Harnack L, Cerhan JR: Association of folate and alcohol with risk of ovarian cancer in a prospective study of postmenopausal women. Canc Causes Contr 2004, 15(10):1085-1093.

18. Genkinger JM, Hunter DJ, Spiegelman D, Anderson KE, Arslan A, Beeson WL, Buring JE, Fraser GE, Freudenheim JL, Goldbohm RA, et al: Dairy products and ovarian cancer: a pooled analysis of 12 cohort studies. Canc Epidemiol Biomarkers Prev 2006, 15(2):364-372.

19. Kushi LH, Mink PJ, Folsom AR, Anderson KE, Zheng W, Lazovich D, Sellers TA: Prospective study of diet and ovarian cancer. Am J Epidemiol 1999, 149(1):21-31.

20. Fairfield KM, Hankinson SE, Rosner BA, Hunter DJ, Colditz GA, Willett WC: Risk of ovarian carcinoma and consumption of vitamins $A, C$, and $E$ and specific carotenoids: a prospective analysis. Cancer 2001, 92(9):2318-2326.

21. Schulz M, Lahmann PH, Boeing H, Hoffmann K, Allen N, Key TJ, Bingham S, Wirfalt $E$, Berglund $G$, Lundin $E$, et al: Fruit and vegetable consumption and risk of epithelial ovarian cancer: the European Prospective Investigation into Cancer and Nutrition. Canc Epidemiol Biomarkers Prev 2005, 14(11 Pt 1):2531-2535.

22. Risch $H A$, Marrett $L D$, Jain $M$, Howe GR: Differences in risk factors for epithelial ovarian cancer by histologic type. Results of a case-control study. Am J Epidemiol 1996, 144(4):363-372.

23. Pearce CL, Templeman C, Rossing MA, Lee A, Near AM, Webb PM, Nagle CM, Doherty JA, Cushing-Haugen KL, Wicklund KG, et al: Association between endometriosis and risk of histological subtypes of ovarian cancer: a pooled analysis of case-control studies. Lancet Oncol 2012, 13(4):385-394. 
24. Rossing MA, Cushing-Haugen KL, Wicklund KG, Weiss NS: Cigarette smoking and risk of epithelial ovarian cancer. Canc Causes Contr 2008, 19(4):413-420

25. Green A, Purdie D, Bain C, Siskind V, Webb PM: Cigarette smoking and risk of epithelial ovarian cancer (Australia). Canc Causes Contr 2001. 12(8):713-719

26. Gwinn ML, Webster LA, Lee NC, Layde PM, Rubin GL: Alcohol consumption and ovarian cancer risk. Am J Epidemiol 1986, 123(5):759-766.

27. Webb PM, Purdie DM, Bain CJ, Green AC: Alcohol, wine, and risk of epithelial ovarian cancer.[see comment]. Canc Epidemiol Biomarkers Prev 2004, 13(4):592-599.

28. Riman T, Dickman PW, Nilsson S, Nordlinder H, Magnusson CM, Persson IR: Some life-style factors and the risk of invasive epithelial ovarian cancer in Swedish women. Eur J Epidemiol 2004, 19(11):1011-1019.

29. Chang ET, Canchola AJ, Lee VS, Clarke CA, Purdie DM, Reynolds P, Bernstein L, Stram DO, Anton-Culver H, Deapen D, et al: Wine and other alcohol consumption and risk of ovarian cancer in the California Teachers Study cohort. Canc Causes Contr 2007, 18(1):91-103.

30. Peterson NB, Trentham-Dietz A, Newcomb PA, Chen Z, Hampton JM, Willett WC, Egan KM: Alcohol consumption and ovarian cancer risk in a population-based case-control study. Int J Cancer 2006, 119(10):2423-2427.

31. Tworoger SS, Gertig DM, Gates MA, Hecht JL, Hankinson SE: Caffeine, alcohol, smoking, and the risk of incident epithelial ovarian cancer. Cancer 2008, 112(5):1169-1177.

32. La Vecchia C, Negri E, Franceschi S, Parazzini F, Gentile A, Fasoli M: Alcohol and epithelial ovarian cancer. J Clin Epidemiol 1992, 45(9):1025-1030.

33. Hartge P, Schiffman MH, Hoover R, McGowan L, Lesher L, Norris HJ: A case-control study of epithelial ovarian cancer. Am J Obstet Gynecol 1989, 161(1):10-16

34. Modugno F, Ness RB, Allen GO: Alcohol consumption and the risk of mucinous and nonmucinous epithelial ovarian cancer. Obstet Gynecol 2003, 102(6):1336-1343.

35. Kuper H, Titus-Ernstoff L, Harlow BL, Cramer DW: Population based study of coffee, alcohol and tobacco use and risk of ovarian cancer. Int J Cancer 2000, 88(2):313-318.

36. Genkinger JM, Hunter DJ, Spiegelman D, Anderson KE, Buring JE, Freudenheim JL, Goldbohm RA, Harnack L, Hankinson SE, Larsson SC, et al: Alcohol intake and ovarian cancer risk: a pooled analysis of 10 cohort studies. Br J Cancer 2006, 94(5):757-762.

37. Kelemen LE, Goode EL: Alcohol intake increases risk of mucinous epithelial ovarian cancer: a meta-analysis. Am J Epidemiol 2007, 165(suppl):S89. Abstract \#355.

38. Rota M, Pasquali E, Scotti L, Pelucchi C, Tramacere I, Islami F, Negri E, Boffetta P, Bellocco R, Corrao G, et al: Alcohol drinking and epithelial ovarian cancer risk. A systematic review and meta-analysis. Gynecol Oncol 2012, 125(3):758-763.

39. Schouten $\sqcup$, Zeegers MP, Goldbohm RA, van den Brandt PA: Alcohol and ovarian cancer risk: results from the Netherlands Cohort Study. Canc Causes Contr 2004, 15(2):201-209.

40. Phillips CV: Publication bias in situ. BMC Med Res Methodol 2004, 4:20.

41. Kobel M, Kalloger SE, Boyd N, McKinney S, Mehl E, Palmer C, Leung S, Bowen NJ, lonescu DN, Rajput A, et al: Ovarian carcinoma subtypes are different diseases: implications for biomarker studies. PLOS Med 2008, 5(12):e232.

42. Wong KK, Gershenson D: The continuum of serous tumors of low malignant potential and low-grade serous carcinomas of the ovary. Dis Markers 2007, 23(5-6):377-387.

43. Risch HA, Bale AE, Beck PA, Zheng W: PGR $+331 \mathrm{~A} / \mathrm{G}$ and increased risk of epithelial ovarian cancer. Canc Epidemiol Biomarkers Prev 2006, 15(9):1738-1741.

44. Rossing MA, Cushing-Haugen KL, Wicklund KG, Doherty JA, Weiss NS: Menopausal hormone therapy and risk of epithelial ovarian cancer. Canc Epidemiol Biomarkers Prev 2007, 16(12):2548-2556.

45. Goodman MT, Lurie G, Thompson PJ, McDuffie KE, Carney ME: Association of two common single-nucleotide polymorphisms in the CYP19A1 locus and ovarian cancer risk. Endocr Relat Canc 2008, 15(4):1055-1060.

46. Ness RB, Dodge RC, Edwards RP, Baker JA, Moysich KB: Contraception methods, beyond oral contraceptives and tubal ligation, and risk of ovarian cancer. Ann Epidemiol 2011, 21(3):188-196.

47. Schildkraut JM, Iversen ES, Wilson MA, Clyde MA, Moorman PG, Palmieri RT, Whitaker R, Bentley RC, Marks JR, Berchuck A: Association between DNA damage response and repair genes and risk of invasive serous ovarian cancer. PLoS One 2010, 5(4):e10061.

48. Schildkraut JM, Moorman PG, Bland AE, Halabi S, Calingaert B, Whitaker R, Lee PS, Elkins-Williams T, Bentley RC, Marks JR, et al: Cyclin E overexpression in epithelial ovarian cancer characterizes an etiologic subgroup. Canc Epidemiol Biomarkers Prev 2008, 17(3):585-593.

49. Terry KL, De Vivo I, Titus-Ernstoff L, Shih MC, Cramer DW: Androgen receptor cytosine, adenine, guanine repeats, and haplotypes in relation to ovarian cancer risk. Cancer Res 2005, 65(13):5974-5981.

50. Terry KL, Tworoger SS, Goode EL, Gates MA, Titus-Ernstoff L, Kelemen LE, Sellers TA, Hankinson SE, Cramer DW: MTHFR polymorphisms in relation to ovarian cancer risk. Gynecol Oncol 2010, 119(2):319-324.

51. Bandera EV, King M, Chandran U, Paddock LE, Rodriguez-Rodriguez L, Olson SH: Phytoestrogen consumption from foods and supplements and epithelial ovarian cancer risk: a population-based case control study. BMC Womens Health 2011, 11:40.

52. Chandran U, Bandera EV, Williams-King MG, Paddock LE, RodriguezRodriguez L, Lu SE, Faulkner S, Pulick K, Olson SH: Healthy eating index and ovarian cancer risk. Canc Causes Contr 2011, 22(4):563-571.

53. Risch HA, Jain M, Marrett LD, Howe GR: Dietary fat intake and risk of epithelial ovarian cancer. J Natl Canc Inst 1994, 86(18):1409-1415.

54. Royar J, Becher H, Chang-Claude J: Low-dose oral contraceptives: protective effect on ovarian cancer risk. Int J Cancer 2001, 95(6):370-374.

55. Glud E, Kjaer SK, Thomsen BL, Hogdall C, Christensen L, Hogdall E, Bock JE, Blaakaer J: Hormone therapy and the impact of estrogen intake on the risk of ovarian cancer. Arch Intern Med 2004, 164(20):2253-2259.

56. Huusom LD, Frederiksen K, Hogdall EV, Glud E, Christensen L, Hogdall CK, Blaakaer J, Kjaer SK: Association of reproductive factors, oral contraceptive use and selected lifestyle factors with the risk of ovarian borderline tumors: a Danish case-control study. Canc Causes Contr 2006, 17(6):821-829.

57. Soegaard M, Jensen A, Hogdall E, Christensen L, Hogdall C, Blaakaer J, Kjaer SK: Different risk factor profiles for mucinous and nonmucinous ovarian cancer: results from the Danish MALOVA study. Canc Epidemiol Biomarkers Prev 2007, 16(6):1160-1166

58. Garcia-Closas M, Brinton LA, Lissowska J, Richesson D, Sherman ME, Szeszenia-Dabrowska N, Peplonska B, Welch R, Yeager M, Zatonski W, et al: Ovarian cancer risk and common variation in the sex hormone-binding globulin gene: a population-based case-control study. BMC Canc 2007, 7:60.

59. Merritt MA, Green AC, Nagle CM, Webb PM: Talcum powder, chronic pelvic inflammation and NSAIDs in relation to risk of epithelial ovarian cancer. Int J Cancer 2008, 122(1):170-176.

60. Ibiebele TI, Parekh S, Mallitt KA, Hughes MC, O'Rourke PK, Webb PM: Reproducibility of food and nutrient intake estimates using a semi-quantitative FFQ in Australian adults. Publ Health Nutr 2009, 12(12):2359-2365.

61. Patterson RE, Kristal AR, Tinker LF, Carter RA, Bolton MP, Agurs-Collins T: Measurement characteristics of the Women's Health Initiative food frequency questionnaire. Ann Epidemiol 1999, 9(3):178-187.

62. Hankin JH, Wilkens LR, Kolonel LN, Yoshizawa CN: Validation of a quantitative diet history method in Hawaii. Am J Epidemiol 1991, 133(6):616-628.

63. Willett W, Sampson L, Stampfer MJ, Rosner B, Bain C, Witschi J, Hennekens CH, Speizer FE: Reproducibility and validity of a semiquantitative food frequency questionnaire. Am J Epidemiol 1985, 122(1):51-65.

64. Rothman KJ, Greenland S: Modern epidemiology. 2nd edition. Philadelphia, PA: Lippincott-Reaven Publishers; 1998.

65. Higgins JP, Thompson SG: Quantifying heterogeneity in a meta-analysis Stat Med 2002, 21(11):1539-1558.

66. Smith-Warner SA, Spiegelman D, Ritz J, Albanes D, Beeson WL, Bernstein L, Berrino F, van den Brandt PA, Buring JE, Cho E, et al: Methods for pooling results of epidemiologic studies: the pooling project of prospective studies of diet and cancer. Am J Epidemiol 2006, 163(11):1053-1064.

67. Willett W, Stampfer MJ: Total energy intake: implications for epidemiologic analyses. Am J Epidemiol 1986, 124(1):17-27.

68. Hosmer DW, Lemeshow SL: Applied logistic regression. New York, NY: John Wiley and Sons, Inc; 2000.

69. Kelemen LE, Goodman MT, McGuire V, Rossing MA, Webb PM, Kobel M, Anton-Culver H, Beesley J, Berchuck A, Brar S, et al: Genetic variation in TYMS in the one-carbon transfer pathway is associated with ovarian 
carcinoma types in the Ovarian Cancer Association Consortium. Canc Epidemiol Biomarkers Prev 2010, 19(7):1822-1830.

70. Seidman JD, Kurman RJ, Ronnett BM: Primary and metastatic mucinous adenocarcinomas in the ovaries: incidence in routine practice with a new approach to improve intraoperative diagnosis. Am J Surg Pathol 2003, 27(7):985-993.

71. Kobel M, Kalloger SE, Huntsman DG, Santos JL, Swenerton KD, Seidman JD, Gilks CB: Differences in tumor type in low-stage versus high-stage ovarian carcinomas. Int J Gynecol Pathol 2010, 29(3):203-211.

72. Gilks CB, Ionescu DN, Kalloger SE, Kobel M, Iving J, Clarke B, Santos J, Le N, Moravan V, Swenerton K: Tumor cell type can be reproducibly diagnosed and is of independent prognostic significance in patients with maximally debulked ovarian carcinoma. Hum Pathol 2008, 39(8):1239-1251.

73. Davies MJ, Baer DJ, Judd JT, Brown ED, Campbell WS, Taylor PR: Effects of moderate alcohol intake on fasting insulin and glucose concentrations and insulin sensitivity in postmenopausal women: a randomized controlled trial. JAMA 2002, 287(19):2559-2562.

74. Calle EE, Kaaks R: Overweight, obesity and cancer: epidemiological evidence and proposed mechanisms. Nat Rev Cancer 2004, 4(8):579-591.

75. Brokaw J, Katsaros D, Wiley A, Lu L, Su D, Sochirca O, de la Longrais IA, Mayne S, Risch H, Yu H: IGF-I in epithelial ovarian cancer and its role in disease progression. Growth Factors 2007, 25(5):346-354

76. Kobel M, Xu H, Bourne PA, Spaulding BO, Shih le M, Mao TL, Soslow RA, Ewanowich CA, Kalloger SE, Mehl E, et al: IGF2BP3 (IMP3) expression is a marker of unfavorable prognosis in ovarian carcinoma of clear cell subtype. Mod Pathol 2009, 22(3):469-475.

77. Parker AS, Cheville JC, Janney CA, Cerhan JR: High expression levels of insulin-like growth factor-I receptor predict poor survival among women with clear-cell renal cell carcinomas. Hum Pathol 2002, 33(8):801-805.

78. Rosendahl AH, Holly JM, Celander M, Forsberg G: Systemic IGF-I administration stimulates the in vivo growth of early, but not advanced, renal cell carcinoma. Int J Cancer 2008, 123(6):1286-1291.

79. Kushi LH, Doyle C, McCullough M, Rock CL, Demark-Wahnefried W, Bandera EV, Gapstur S, Patel AV, Andrews K, Gansler T: American Cancer Society Guidelines on nutrition and physical activity for cancer prevention: reducing the risk of cancer with healthy food choices and physical activity. CA Cancer J Clin 2012, 62(1):30-67.

80. Seitz HK, Stickel F: Molecular mechanisms of alcohol-mediated carcinogenesis. Nat Rev Cancer 2007, 7(8):599-612.

81. World Cancer Research Fund/American Institute for Cancer Research: Food, nutrition, physical activity, and the prevention of cancer: a global perspective. Washington, DC: AICR; 2007.

82. Goodman MT, Tung KH: Alcohol consumption and the risk of borderline and invasive ovarian cancer. Obstet Gynecol 2003, 101(6):1221-1228.

83. Manach C, Scalbert A, Morand C, Remesy C, Jimenez L: Polyphenols: food sources and bioavailability. Am J Clin Nutr 2004, 79(5):727-747.

84. Scalbert A, Manach C, Morand C, Remesy C, Jimenez L: Dietary polyphenols and the prevention of diseases. Crit Rev Food Sci Nutr 2005, 45(4):287-306

85. Lee JE, Hunter DJ, Spiegelman D, Adami HO, Albanes D, Bernstein L, van den Brandt PA, Buring JE, Cho E, Folsom AR, et al: Alcohol intake and renal cell cancer in a pooled analysis of 12 prospective studies. J Natl Canc Inst 2007, 99(10):801-810.

86. Gavallos G, Tawfik O, Herrell D, Langenstroer P: Renal-ovarian axis: a case report and review. Urology 2003, 62(4):749.

87. Matsumura N, Mandai M, Okamoto T, Yamaguchi K, Yamamura S, Oura T, Baba T, Hamanishi J, Kang HS, Matsui S, et al: Sorafenib efficacy in ovarian clear cell carcinoma revealed by transcriptome profiling. Canc Sci 2010, 101(12):2658-2663.

88. Zorn KK, Bonome T, Gangi L, Chandramouli GV, Awtrey CS, Gardner GJ, Barrett JC, Boyd J, Birrer MJ: Gene expression profiles of serous, endometrioid, and clear cell subtypes of ovarian and endometrial cancer. Clin Cancer Res 2005, 11(18):6422-6430.

89. Risch HA: Hormone replacement therapy and the risk of ovarian cancer. Gynecol Oncol 2002, 86(2):115-117.

doi:10.1186/1471-2407-13-28

Cite this article as: Kelemen et al.: Recent alcohol consumption and risk of incident ovarian carcinoma: a pooled analysis of 5,342 cases and 10,358 controls from the Ovarian Cancer Association Consortium. BMC Cancer 2013 13:28.

\section{Submit your next manuscript to BioMed Central and take full advantage of:}

- Convenient online submission

- Thorough peer review

- No space constraints or color figure charges

- Immediate publication on acceptance

- Inclusion in PubMed, CAS, Scopus and Google Scholar

- Research which is freely available for redistribution 